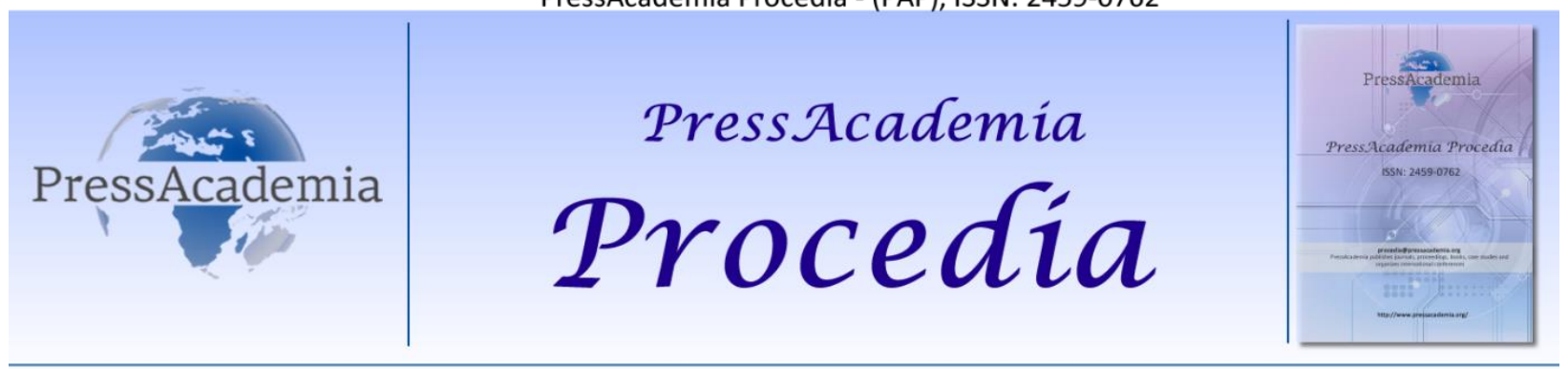

2nd World Conference on Technology, Innovation and Entrepreneurship

May 12-14, 2017, Istanbul, Turkey. Edited by Sefer Şener

\title{
A THEORETICAL STUDY ON WORKPLACE RECREATION: SUGGESTION ON ITS APPLICABILITY IN TOURISM ENTERPRISES
}

\author{
DOI: 10.17261/Pressacademia.2017.544 \\ PAP-WCTIE-V.4-2017(36)-p.273-280
}

Ilke Basarangil

Kırklareli University Tourism Faculty, Kırklareli, Turkey ilkekaya33@hotmail.com

\begin{abstract}
In tourism, which is a labor-intensive sector, the fact that employees work under excessive stress and pressure can cause work exhaustion, job dissatisfaction and inefficient work. Tourism business managers have begun to care much more about the impact of workplace recreation on productivity in order to prevent all of this. Workplace recreation, when implemented by the managers, can contribute to job satisfaction and productivity by allowing the employee to spend leisure time more efficiently and productively by providing working time and leisure time balance. Therefore, the aim of this study is to carry out a theoretical examination on the workplace recreation and to present various suggestions to the sector managers in tourism for their applicability in tourism enterprises, as well as evaluating the benefits of business recreation to tourism businesses, employees and the economy of the country. For this purpose, efforts have been made to reveal the relationship between leisure time and work efficiency in this study and then evaluations and suggestions about the applicability of workplace recreation in tourism enterprises have been presented. This study presents a theoretical framework guiding future researches.
\end{abstract}

Keywords: Leisure time, workplace recreation, work productivity, tourism enterprises JEL Codes: L83, Z32

\section{INTRODUCTION}

The way to success today goes through effective and productive work and using the time programmatically in the direction of determined priorities. There is always the opportunity to enjoy, rest and see the problems in a regular and systematic way (Batlaş and Batlaş, 1998: 14). Workplace recreation is necessary for those who have to adapt to the stressful lifestyle of industrialization and urbanization, to overcome tension in the workplace and maintain their psychological balance. In industrialized societies, work and living conditions alienate individuals to their own societies. This alienation is a very negative influence. These negative situations are eliminated so that the individuals can renew themselves by creating leisure time and recreation opportunities (Önsoy, 1984). Despite the fact that employees were not entitled to a paid leave during the 1880s, it is exhibited that they went on vacation during periods such as Easter and Official Bank Holiday. However, in the last century, the annual working period has been reduced from 3,000 to 2200 hours, therefore the resting periods of the individuals have increased. The 3-8 Theory that recently emerged on leisure time includes 8 hours of work, 8 hours of relaxation and 8 hours of rest. Countries that have considered leisure time and vacation as an important right for employees in the 20th century accepted the annual paid leave right on different dates (Hacıoğlu et al., 2015: 18-19). In addition, the health conditions of employees and the inadequacy of their working environment led to the emergence of the workplace recreation in the United States towards the end of the 19th century and to the more serious consideration towards it; at the beginning of the 20th century the workplace services for employees were increased to prevent conflicts between employees and employers (Kesim, 2016: 132-133). Growth of the world economy, technological developments and acceleration of transportation and increase of welfare level have increased the leisure time of people. The increase in leisure time necessitated the tendency to use leisure time (Güngörmüş and Yetim, 2006: 654). Efficient use of leisure time is both a part of education and an educational tool. This tool is an important key to personal productivity as well as a basis for the individual's physical, mental and social development (Dawer and Pangraz, 1975). Routine lifestyle influences work efficiency, health and psycho-social levels of employees that are worn out in the face of today's stressful living conditions and the difficulties brought about by intense working life. As a consequence, numerous disadvantages such as serious heart 
diseases, obesity, loss of immunity system, loss of manpower and efficiency, frequent illness and non-response to treatment in the individuals can be removed or reduced by the good evaluation of leisure time (Hazar, 2014: 12). Overworking employees that cannot balance work and family life, having problems in both aspects. As a result, the productivity of the employees is adversely affected, the behaviors such as the tendency for being late, leaving work etc. increase. In this context, overworking, workaholic employees should be determined by their mangers and directed to efficient (Temel, 2006: 104). The fact that working time and leisure time are not managed in a balanced manner is among the reasons leading to job dissatisfaction in working life. Therefore, the aim of this study is to carry out a theoretical examination on the workplace recreation which cannot get much place in the tourism sector in our country. In 2009, a research writing by American Daily Beast indicated that USA was the first country in the world to spend most of its leisure time watching TV, followed by Turkey in the fourth place (Koç, 2015: 392). As a society that cannot use its leisure time with passive recreational activities, efforts have been made to develop various suggestions for the managers of tourism enterprises within the context of workplace recreation as part of better planning of leisure time at workplaces. Tourism enterprise managers can make active recreational activities at the workplace taking these suggestions as basis and then increase the efficiency of their employees.

\section{THE CONTRIBUTIONS OF THE PARTICIPATION IN THE LEISURE TIME ACTIVITIES TOWARS THE WORK PRODUCTIVITY}

Leisure and recreation studies were first conducted in the United States in the 1950s among socio-economic structures and activities, on the concepts of race and nationality in the 1960s and on the lifestyle and participation due to the increase in the elderly population in 1970s. While these issues were approached individually until 1980s, they were approached collectively after 1990s (Lee et al., 2001). In the Turkish society, leisure and recreation habits have been established in the Seljuk period by the birth of guilds and the tradition of ahi community. The male members of the guild participated in meetings with dinner and engaged in workplace recreation. Ahilik (artisan solidarity organization), during the Ottoman period, took part in recreational activities which brought sports and festivals conducted for the villages and even for the immigrants. The organization's top priority during these activities was to raise the youth with sportsmanship (Kesim, 2016: 133). According to Pennington-Gray and Kertetter (2001), upon the examination of the historical development process of leisure time, reducing working hours in business life and increasing the vacation periods in return have occurred in the following categories: (1) daily working hours were reduced by reducing working hours from 10 to 14 hours to 8 hours, (2) reducing weekly working time to 6 days from 5 days, and provided 2 days of leisure time per week to reduce weekly working hours, (3) the annual leave of 2 weeks (which began to be implemented in various European countries since 1936) was increased to 4 weeks, during which the annual pay period started to be reduced and the annual working hours were reduced, (4) the early retirement and teaching patterns changed, reducing the work life and thus multiplying the leisure time (Hacıoğlu et al., 2015: 21-22). The definition of leisure time by the International Association of Tourism Experts (AIEST) is as the amount of time that can be used after one person has satisfied the needs of being, job or work (Ince, 2000: 11). Leisure time can also be expressed in short as the time when people are saved from activities that they have to perform in order to maintain their life (for example, eating and drinking, sleeping, work, etc.). According to İnce (2000: 11), leisure time can be classified as (1) touristic leisure time, (2) sportive leisure time, (3) artistic leisure time, (4) social leisure time. Hacıŏlu and Gökdeniz (1998) listed the characteristics of the leisure time as follows:

- $\quad$ Providing the functions of decreasing the physical and mental exhaustion brought by the working life, resting and spending spare time,

- Being an important task bearing responsibility to the individuals,

- Allowing entertainment and renewal allowing the escape from monotony,

- $\quad$ Being capable of contributing to physical, mental and spiritual development and of developing personality during new conditions (Hacıoğlu et al., 2015: 28).

Leisure time is a time period that is needed in eliminating all kinds of negativities such as stress, physical fatigue and psychological deprivation caused by the work of the individuals (Demir and Demir 2014: 82). The feeling of stress and oppression within the working life creates a negative effect on the work productivity and individuals need to act more, innovate and change (Gökdeniz, 2003: 60). Apart from people's routine lives; relaxation, enjoyment and increased productivity at work are achieved through recreational activities in leisure time (Karaküçük, 1997: 84). If productivity is conceptually taken into account, in short, it is the ratio of the outcome (e.g. goods or services) obtained to the input or inputs (e.g. manpower, capital, technology, etc.). Efficiency, used synonymously with productivity, is a measure of being efficient, a ratio showing how much of the inputs (resources) used to produce outputs are transformed into productive output (Taner, 2005: 6). People who work tirelessly all year round intend to spend the remaining time and money out of which has been spent on their obligatory needs, on making use of the leisure time and participating the activity of tourism. Achieving the awareness that leisure time is an important need increases the demand for tourism and recreational activities 
(Crotts and Raaij, 1995: 73). The studies indicate that participation in both physical and non-physical leisure activities decreases depression and anxiety, produces a positive mood, increases respect for oneself and ideas, facilitates personal interaction, enhances general psychological well-being and life satisfaction in business life (Iso-Ahola, 1997). One of the studies exhibit that the use of physically-active leisure time a $50 \%$ reduction in mortality rates for health (Blair and Connelly, 1996). The evaluation of leisure time is a necessity that emphasizes its weight and possibilities tremendously as a result of the amount of production emerged and achieved thanks to the industrialization and the regulation of working life. Fletcher (1993) notes that working time-leisure time factors are examined as options among factors influencing unhappiness in business life by the employees. Clark et al. (1988) revealed that productivity increases with teamwork. Roberts et al. (1989) found that people who take inefficient leisure time are less healthy than those who use leisure time efficiently. The main reason why people do not abandon physical activity is due to the proven effectiveness of exercises in reducing heart diseases, heart attacks, colon cancer, diabetes and obesity. The reason for the failure in establishing the balance between business life and leisure is people's increased work exhaustion. Work exhaustion occurs as an individual stress event, a psychological symptom of emotional exhaustion, breaking of personal relationships, and a decrease in individual achievement (Maslach and Goldberg, 1998). Stanton-Rich and Iso-Ahola (1998) found as a result of their study on work exhaustion and leisure time that the more effective leisure time a person has equals to the higher the leisure time satisfaction and personal success and the lower the emotional burnout level and lower ratio of breaking personal relationships. Passive leisure time activities (such as watching TV) are a temporary solution to work exhaustion. However, personal success and personal effectiveness arise from the need for intentional, mental and physical leisure activities and can provide continuous protection against exhaustion (Csikszentmihalyi, 1990). The factors preventing the increase in the productivity in the workplace include (1) the insufficiency of the individuals forming the management level, (2) the insufficiency of the organization, (3) the lack of motivation factors to incentivize the manpower to work more within the organization, (4) the insufficiency of the physical working conditions, (5) lack of a good employee evaluation system, (6) high employee replacement speed rate, (7) lack of a fair and balanced payment system and (8) the failure to fulfill the leisure time needs of the employees (Boyacı, 1991: 70-71). The importance of workplace recreation becomes more prominent, especially considering the fact that the needs of leisure-time employees in a labor-intensive industry, such as the tourism industry, are considerably high. Proposals for implementation of workplace recreation in the tourism sector have been tried to be developed for tourism business managers.

\section{A THEORETICAL FRAMEWORK OF THE APPLICABILITY OF THE WORKPLACE RECREATION IN TOURISM SECTOR}

Towards the end of the 19th century, several initiatives were launched in the United States for employees due to inadequate health conditions and worsening working conditions. The purpose of these initiatives is to improve the daily living conditions of the employees and help them work in better conditions in the workplace and integrate with the workplace (Kesim, 2016: 132). Kozan (2006) defines Workplace Recreation as the artistic, cultural and sportive activities, excursions and organizations held in public institutions and bodies in the private sector for increasing work productivity and employee health (Göker, 2014: 198). Recreational activities in the area of business productivity contribute employees in developing their morale and motivation, socializing, achieving psychological and physical satisfaction, strengthening emotions such as helping each other and solidarity (Göker, 2014: 198). Industrial and workplace recreation is the provision of special facilities for employees, special individuals, to increase commercial profits. Thus, a happy workforce can be achieved that can generate more profits with more efficiency and output. Recreational services and facilities offered by businesses to workshops would affect the following factors (Torkildsen, 2012: 306);

- More love for humanity,

- Being healthy for work,

- Decrease in the personnel replacement,

- Company image,

- Company principles,

- Employee stress.

According to Mendell (1984), businesses provide workplace recreation to increase work efficiency, enhance employee motivation, and provide cost efficiency; the enterprises providing health benefits to the employees via fitness programs and therefore saving on healthcare expenses can be set as examples (Leitner and Leitner, 2004: 78). Table 1 below exhibits in detail the potential gains of the workplace recreation to the workplace, potential gains to its employees and potential gains to the state.

Table 1: Potential Gains of Workplace Recreation Towards the Workplace, Employee and the State 


\begin{tabular}{|c|c|c|}
\hline $\begin{array}{l}\text { Potential Gains of Workplace } \\
\text { Recreation } \\
\text { Workplace }\end{array}$ & $\begin{array}{l}\text { Leisure Time Skill and Life Standard } \\
\text { Gains of the Workplace Recreation } \\
\text { Towards the Employee }\end{array}$ & $\begin{array}{l}\text { Potential Gains of Government } \\
\text { Recreation Towards the State }\end{array}$ \\
\hline $\begin{array}{l}\text { Making the workplace appealing } \\
\text { for the employees. }\end{array}$ & Skill development & $\begin{array}{l}\text { Contribution to the increase in } \\
\text { productivity in the workplaces }\end{array}$ \\
\hline $\begin{array}{l}\text { Increasing the production quality } \\
\text { and productivity. }\end{array}$ & Decision-making & $\begin{array}{l}\text { Economic revival as a result of the } \\
\text { workplaces being appealing }\end{array}$ \\
\hline $\begin{array}{l}\text { Providing integration with the } \\
\text { workplace, }\end{array}$ & Problem-solving & $\begin{array}{l}\text { Minimizing the health expenditures } \\
\text { in the workplaces }\end{array}$ \\
\hline $\begin{array}{l}\text { Decreasing the workplace } \\
\text { accidents. }\end{array}$ & Planning & $\begin{array}{l}\text { Increasing the safety and security in } \\
\text { the workplaces with healthy, fit and } \\
\text { happy employees (Decrease in the } \\
\text { work accidents). }\end{array}$ \\
\hline Resolving the workplace disputes. & $\begin{array}{l}\text { Developing cooperation with other } \\
\text { employees }\end{array}$ & $\begin{array}{l}\text { Creating new areas of employment } \\
\text { to the workplace recreation leaders, } \\
\text { event specialists and individuals with } \\
\text { sports education }\end{array}$ \\
\hline $\begin{array}{l}\text { Decreasing the workplace } \\
\text { compensation claims }\end{array}$ & Being capable of evaluation & \\
\hline $\begin{array}{l}\text { Minimizing the resignations from } \\
\text { the job }\end{array}$ & Escaping the monotony & \\
\hline Increasing the business satisfaction. & Serving in better conditions. & \\
\hline $\begin{array}{l}\text { Preventing the absenteeism to } \\
\text { work. }\end{array}$ & Getting new hobby habits. & \\
\hline $\begin{array}{l}\text { Reinforcing the moral levels of the } \\
\text { employees. }\end{array}$ & Desire to maintain a healthier life. & \\
\hline $\begin{array}{l}\text { Harmonization between the } \\
\text { employer and employees. }\end{array}$ & Improving the daily life conditions & \\
\hline $\begin{array}{l}\text { Reinforcing the relations and } \\
\text { solidarity between the employees. }\end{array}$ & Having flexible working hours. & \\
\hline $\begin{array}{l}\text { Decreasing the health expenditure } \\
\text { shares of the employers. }\end{array}$ & $\begin{array}{l}\text { Showing improvements on sports, } \\
\text { health, social and cultural areas. }\end{array}$ & \\
\hline $\begin{array}{l}\text { Providing integration between the } \\
\text { workplace and surrounding public. }\end{array}$ & & \\
\hline
\end{tabular}

Source: Kesim, 2016: 145-146

The intense physical working environment in the hotel enterprises is physically exhausting for the employees. Hotel staff nights, which could be an example for business recreation, are practiced in almost all hotel enterprises. These nights of motivation for employees indicate positive results for socialization, reward and workplace loyalty (Göker, 2014: 198). Akova and Bayhan (2015) investigated the relationship between organizational loyalty and recreational facilities in accommodation enterprises. According to the results of the research, the emotional commitment and continuing loyalty of the employees supported by recreational leisure activities opportunities were found to be higher than the ones that did not provide similar opportunities. Mokaya and Gitari (2012), on the other hand, found in their research that relaxation and feeling great (83\%), stress reduction and developing concentration (62\%), confidence and feeling of self-esteem (59.7\%) and increased health $(53,2 \%)$ are among the reasons for workplace recreation demand among the employees. Workplace recreation was found to have a positive effect on employee performance variables (92\%), customer satisfaction and service quality $(72 \%)$ and productivity (77.5\%), which are the employee performance variables. Mbaabu (2013) examined the effects of workplace recreation on the performance and health of employees and revealed that physical fitness programs and mental health programs have had a positive impact on occupational performance and health. Sevin and Küçük (2016) concluded that, according to the results of the research, the employees' working performances have increased as the levels of participation in recreation activities in the leisure time of employees in the hotel business increase. Demir and Demir (2014) conducted research on the leisure time needs of employees in the tourism sector and the factors that affect leisure time satisfaction. According to the results of the research, the participation of the individuals in various leisure activities as an end result of socialization affects leisure time satisfaction in terms of both mental and physical condition. Sop (2014) examined the relationship between work pressure, work-leisure time conflict, job satisfaction and life satisfaction on hotel employees. According to the results of the research, it was concluded that long shift hours increased the work-free time conflict. 
The high relationship between employee satisfaction and customer satisfaction has made it a priority for businesses to adopt internal marketing practices for employees today (Kozak et al., 2011: 141). The managers increasing the employees' commitment the enterprise makes a significant contribution to their ability to do their job better, to better use their professional knowledge and skills and thus to increase the quality of service. Therefore, the contribution of the employee that is integrated with the job s/he is doing and is satisfied with the job to the enterprise will be higher (Öztürk and Seyhan, 2005: 137-138). Enterprises that care about the employees sufficiently, value them and meet their recreational needs will make an important leap in the development of service quality (Öztürk and Seyhan, 2005: 127-128). As a result, any recreational activity within the workplace will increase the motivation of the employees and their commitment to the workplace. In addition, constantly routine work affects employees psychologically, so the activities they participate in will create psychological relief. Activities such as picnics, entertainment, environmental trips are very important for the efficiency of the staff. In addition to spiritual satisfaction and benefit, it also provides physical benefits (Göker, 2014: 198).

\section{EVALUATION and SUGGESTIONS}

The workplace recreation that started in the 19th century and later and was carried out in our country in 1976 under the leadership of İşbank's football, basketball, volleyball, tennis, table tennis and chess tournaments (Kesim, 2016: 133) today continues with the implementations of workplace recreation organized by institutional enterprises for their employees by corporate enterprises such as Koç, Eczacıbaşı, Sabancı, Migros etc. In addition to this, Dedeman Hotels (Antalya), with the motto 'Dedeman is my unique guest production', had the cafeteria specially renovated for the staff and special cups with names and special letters of each personnel's initials have been made. Thus, coffee breaks have made recreation hours more enjoyable. In Güral Wellness Convention (Sapanca); with the personnel night organization every year, lunch or dinner is eaten together with all the staff in Güral Sapanca garden to motivate the staff on certain days. Barbecue days are organized. At RichmoundNuna Wellness-Spa, barbecue is organized every New Year's Ece and a New Year's Eve lottery is conducted among the staff. This lottery was arranged for the benefit of staff from hotel facilities. Lale Butique Hotel (Sapanca) organizes barbecues on certain days. On Ramadan days, all the staff goes to a place for iftar. The employees of the month receive an extra amount in their salaries. They send their personnel to vacation and everything is covered by the hotel owner. The staff is rewarded within working hours: the desserts in the kitchen or the menu of the day are being eaten in the hotel restaurant or in the garden with a conversation. Hotel owner also organizes cinema day events for his personnel. Examples of the hotel can also be given Hilton, Conrad and Ritz Carlton. In similar ways, activities in different venues are organized within the scope of various workplace recreation, but the recreational activities organized are basically not sufficient. Sahibinden.com Company has one of the best working office in Turkey. This company has recreational areas such as basketball and table tennis in the company, as well as a play station room, a TV room and a cafeteria._There is a running track in the company. There are gingers (segway) in the company to move quickly. The company uses the world's best chairs and all employees benefit from these chairs. In addition, a room was designed in the form of a jungle forest for brain storms.

The enterprises that attach importance to workplace recreation believe that the superiority in the competition would be realized with qualified and eligible manpower and they realized that quality and productivity firstly comes through the employees. Workplace recreation is recreational activities and facilities with cultural, artistic, athletic, medical and social purposes which are implemented for the employees in order to improve work environments, increase their motivation, provide physical and mental satisfaction as well as work satisfaction and productivity, reduce their rapidity of replacement and help them socialize. Workplace recreation has significant benefits for enterprises as well as for employees and countries:

(1) With workplace recreation applications in tourism enterprises;

- Work satisfaction and work productivity of the tourism employees may be increased,

- Possible accidents in the workplace may be avoided,

- The service quality of the work offered may be increased,

- The rapidity of the employee replacement may be decreased,

- The teamwork between the employees may be increased,

- The absenteeism or being late to work may be prevented,

(2) With workplace recreation applications for tourism employees; the following may be achieved;

- Being healthy individuals via achieving physical and spiritual renewal,

- Change in social and cultural life, 
- Improvement in leadership and problem-solving skills,

- Being more prone to cooperation and teamwork,

- Avoiding stress and a routine life,

- Increasing the work satisfaction and organizational commitment by working in better conditions,

(3) The contributions created by the workplace recreation applications to the country economy are listed below;

- The service quality offered in the tourism enterprises may be increased and more visitors can be hosted due to the fact that the employees are more productive in the workplaces,

- The service quality in the tourism sector may be increased and contributions can be made to achieving compared superiority in economy,

- Workplace accidents may be prevented and less health expenditures may be made.

The importance of employees in increasing the service quality cannot be denied in labor-intensive a sector such as tourism, which has seasonal characteristics and long working hours. One of the important things that tourism managers in today's tourism should not ignore is to create complementary recreational programs that can improve the leadership skills of the employees working in tourism, increase their professional knowledge and skills and contribute to their development. In the literature, it is observed that work satisfaction, work productivity and organizational commitment of the employees whose recreational needs are fulfilled by the tourism enterprise managers are high (Mbaabu, 2013, Demir and Demir, 2014, Akova and Bayhan, 2015, Sevin and Küçük, 2016). Therefore, a theoretical evaluation on workplace recreation was carried out in this study and efforts were made to develop suggestions for workplace recreation for its applicability in the tourism sector. It can be argued that tourism business managers can increase the employee satisfaction and commitment and decrease the rapidity of the employee replacement by applying one or more of the following proposals for workplace recreation.

Health Recreation Suggestion - 1: It can be procured that tourism enterprise employees can benefit from fitness, spa, pool, Turkish baths when the customers are not actively using it. Spa, skin care, massages, haircuts, etc. can be offered as a free service to the employees who in particular encounter with the customers occasionally. It may be possible for them to benefit from these services free of charge to any other business that offers spa services to their wishes.

Health Recreation Suggestion - 2: In order to encourage an active life, managers should cycle or walk when going to work if the distance between the house and work is convenient. Thus, heart health can be maintained and purification from stress can be achieved.

Recreation Suggestion with Social Purposes - 3: The employees may be benefited from the sportive recreation of the coastal hotels that include water sports (such as sailing, surfing etc.) on their birthdays or when they are selected as the employee of the month. In addition, when employees have newborn babies, celebratory parties or dinner meetings on special occasions can be arranged. It will be seen that such activities strengthen community loyalty.

Recreation Suggestion with Social Purposes - 4: Corporate social responsibility projects can be carried out with employees who can show examples of social responsibility by visiting disabled people, orphans and elderly people. Also, street animals may be fed and clothing and textile products can be provided to the people in need. Thus, employees will achieve satisfaction for their happiness and happiness of others by providing support to social life.

Recreation Suggestion with Social Purposes - 5: Employees can be provided with social areas where they can relax and socialize outside work hours. Billiards, table tennis, darts, etc. can be made available on for those who work on this area. With a music box, the social space can be made more joyful. In addition, a massage chair may be included in the social area for the employees to relax and rest a bit within the facilities for the enterprises.

Touristic Recreation Suggestion - 6: A holiday package of one week or less per year may be gifted to reward employees with high levels of performance. Employees who achieve outstanding success can be provided with a free boat trip, aquapark, a theme park or a fun experience at leisure centers on this vacation.

Artistic Recreation Suggestion - 7: In addition, from time to time; the motivation of the employees may be increased with tickets for cinema, theater, concerts, festivals, folk dances etc. in order to reward small achievements.

Group Recreation Suggestion - 8: Food and beverage department employees and cooks can participate in contests where they can meet the world cuisines and make presentations, exchange information and have fun. They may have the opportunity to taste the Italian, French, Far East etc. delicacies and have a good time. 
Sportive Recreation Suggestion - 9: Football, basketball, volleyball etc. teams for sportive recreation may be founded in contribution to the development of the team culture. Sports clubs may be founded, aiding the employees to preserve the physical and mental health and to make use of their leisure time more actively. These competitions may be converted to festivals/picnics and made traditional every year. Employees can be provided with recreation areas where play stations, table tennis, basketball playing areas is played.

In this study, a theoretical review was carried out on workplace recreation and recreational suggestions were developed in different categories for applicability in the tourism sector. It can be argued that the work will contribute to the field from the theoretical perspective. Future research can also carry out field research to find out more clearly the contribution of business recreation to the tourism sector and to find out how far it has been applied in the industry.

\section{REFERENCES}

Akova, O. and Bayhan, İ. (2015). “Örgütsel Bağlılık ve Rekreasyonel İmkânlar Arsındaki İlişki: Antalya'da Konaklama İşletmelerinde Çalışanların Üzerine Bir Araştırma”, Uluslararası Sosyal Araştırmalar Dergisi, 8 (38), s.789-805.

Batlaş, A. and Batlaş, Z. (1998). Stres ve Başa Çıkma Yolları. İstanbul: Remzi Kitabevi.

Blair, S. and Connelly, J. (1996). "How Much Physical Activity Should We Do? The Case For Moderate Amounts And Intensities of Physical Activity", Research Quarterly for Exercise and Sport, 67: s.193-205.

Boyacı, C. (1991). Personel Yönetiminde Beşeri Kaynakların Korunması Açısından Iş Koşullarının Iyileştirilmesi ve Işte Verimliliğe Olan Etkisi Üzerine Bir Uygulama, Antalya: Akdeniz Üniversitesi Basımevi, Yayın no: 36.

Clark P., Hantrais L., Hassard J. and Starkey K. (1988). The porous day and temps choisi, an enquiry into the appropriation of time. (Working paper 88-4), Department of Economics and Management Science, University of Keele, Keele.

Crotts, C.J. and Raaij, F. V. (1995). Economic Psychoogy of Travel and Tourism, NewYork: The Haworth Hospitality Press.

Csikszentmihalyi, M. (1990). Flow: The Psychology of Optimal Experience, New York: Harper and Row.

Dawer P.W. and Pangraz R.P. (1975). Dynamic Physical Education For Elementary School Children, 4 th Edition, USA: Washington.

Demir, M. and Demir, Ş.S. (2014). "İ̧̧görenlerin Serbest Zaman Gereksinimi Ve Serbest Zaman Doyumunu Etkileyen Faktörler", İ̧̧letme ve iktisat Çalışmaları Dergisi, 2 (3), s.74-84.

Fletcher C. (1993). "The İnterrelationship of Managers Work Time And Personal Time”, Personnel Review, 22 (2), s.56-64.

Göker, G. (2014). Rekreasyonda Yeni Trendler (içinde Rekreasyona Giriş, Ed. Ali Yaylı). Ankara: Detay.

Gökdeniz, A. (2003). "Yerel Gündem 21 ve Sürdürülebilir Turizm Politikaları Çerçevesinde Eko Turizm”, Ekonomik ve Teknik Standart, Yıl 42, Sayı 496.

Güngörmüş, A.H. and Yetim, A.A. (2006). “Ankara'daki Beden Eğitimi Ve Spor Öğrenimi Veren Yüksek Öğretim Kurumlarında Görev Yapan Öğretim Elemanlarının Boş Zamanlarını Değerlendirme Biçimlerinin Araştırılması”, Kastamonu Eğitim Dergisi, 14 (2), s.653-666.

Hacıoğlu, N., Gökdeniz, A. and Dinç, Y. (2015). Boş Zaman ve Rekreasyon Yönetimi, Ankara: Detay.

Hazar, A. (2014). Rekreasyon ve Animasyon, Ankara: Detay.

Iso-Ahola, S. (1997). A Psychological Analysis of Leisure and Health. J.T. Haworth (ed.) Work, Leisure and Well-being. London: Routledge.

İnce, C. (2000). Turizm Isşletmelerinde Rekreasyon ve Animasyon, Ankara: Turhan Kitabevi.

Karaküçük, S. (1997). Rekreasyon, Ankara: Ankara Basımevi.

Kesim, Ü. (2016). İs Yeri Rekreasyonu (içinde Rekreasyon Bilimi, Ed. Prof.Dr. Suat Karaküçük). Ankara: Gazi.

Koç, E. (2015). Tüketici Davranışı ve Pazarlama Stratejileri, 6. Baskı, Ankara: Seçkin.

Kozak, N., Özel, Ç.H. ve Yüncü, D.K. (2011). Hizmet Pazarlaması, Ankara: Detay.

Lee, J. H., Scott, D. and Floyd, M. F. (2001). "Structural Inequalities In Outdoor Recreation Participation: A Multiple Hierarchy Stractification Perspective", Journal of Leisure Research, 33 (4), s. 427-449.

Leitner, M. J.; Leitner, S. F. and Associates. (2004). Leisure enhancement (3 rd ed.) New York: Haworth Pres.

Maslach, C. and Goldberg, J. (1998). "Prevention of Burnout: New Perspectives", Applied And Preventive Psychology, (7), s.63-74. 
Mbaabu, C. M. (2013). Effect of Workplace Recreation on Employee Wellbeing And Performance: A Case of The Commission For University Education (Cue). Kenyatta University: Project Submitted to The School of Business In Partial Fulfillment of The Requirement For The Degree of Master of Business Administration.

Mokaya, S. O. and Gitari, J.W. (2012). "Effects of workplace recreation on employee performance: The case of Kenya Utalii College", International Journal of Humanities and Social Science, 2 (3), s.176-183.

Önsoy, C. (1984). Osmaniye İskenderun Kıyı Kesiminde Ekolojik Planlama IIlkelerine Uygun Alan Kullanımının Araştııılması.(Yayınlanmamış Doktora Tezi) Ç.Ü. Fen Bilimleri Enstitüsü, Peyzaj Mimarlı̆ıı Anabilim Dalı, no: 53, Adana.

Öztürk, Y. and Seyhan, K. (2005). "Konaklama işletmelerinde sunulan hizmet kalitesinin arttııılmasında işgören eğitiminin yeri ve önemi", Ticaret ve Turizm Eğitim Fakültesi Dergisi, 1, 121-140.

Roberts, K., Lamb, K. L., Dench, S. and Brodie, D.A. (1989). "Leisure Patterns, Health Status And Employement Status", Leisure Studies, (8), s. 229-235.

Sevin, H.D. ve Küçük, S. (2016). "Işgörenlerin Rekreasyonel Etkinliklere Katılım Düzeyleri Ille Çalışma Performansları Arasındaki Ilişkiyi Belirlemeye Yönelik Bir Araştırma", Journal of Recreation and Tourism Research, 3 (1), s.24-31.

Sop, S.A. (2014). "Işs Baskısı, İs-Serbest Zaman Çatışması, Meslek Memnuniyeti Ve Yaşam Doyumu ilişsisi Üzerine Bir İnceleme”, Turizm Akademik Dergisi, 1(1), s.1-14.

Stanton-Rich, M. and Iso-Ahola, S. (1998). "Burnout and Leisure”, Journal of Applied Social Psychology, 28: s.1931-50.

Taner, B. (2005). Ağırlama Endüstrisinde Verimlilik Yönetimi, İstanbul: Beta Basım.

Temel, A. (2006). “Organizasyonlarda İşkolizm ve İşkolik Çalışanlar”, İş,Güç” Endüstri Ilişskileri ve Insan Kaynakları Dergisi, (8), 2, s.104-127.

Torkildsen, G. (2012). Leisure and Recreation Management (Fourth Edition). London \& NewYork: Taylor and Francis. 